\title{
Influence of food density and temperature on ingestion, growth and settlement of Pacific oyster larvae, Crassostrea gigas
}

\author{
B. Rico-Villa ${ }^{a}$, S. Pouvreau ${ }^{a}$ and R. Robert ${ }^{a}$, \\ a Ifremer, Département de Physiologie Fonctionnelle des Organismes Marins, Station Expérimentale d'Argenton, \\ Presqu'île du Vivier, 29840 Argenton, France \\ *: Corresponding author : R. Robert, Tel.: +33 2 98895105; fax: +33 298895777, email address : \\ rrobert@ifremer.fr
}

\begin{abstract}
:
Ingestion, growth and metamorphosis of Pacific oyster, Crassostrea gigas, larvae were studied under controlled conditions of food density and temperature using a combination of a flow-through rearing system and a hydrobiological monitoring device. In a first experiment larvae were exposed to three different phytoplankton densities $(12,20$ and 40 cells $\mu \mathrm{l}-1)$ while in a second trial larvae were reared at five different temperatures $\left(17,22,25,27\right.$ and $\left.32^{\circ} \mathrm{C}\right)$. Both food concentration and temperature significantly affected the larval physiology throughout the entire development from D-veliger to young spat. Larvae survived over a wide range of both environmental parameters with high survival at the end of experiments. The feeding functional response provided the maximal ingestion rate $(50000$ cells larva-1 day-1) which occurred at an algal density of 20 cells $\mu$ l- 1 surrounding the larvae and $25^{\circ} \mathrm{C}$. At the highest temperature $\left(32{ }^{\circ} \mathrm{C}\right)$, maximal growth and metamorphosis performances were reached in less than 2 weeks while the lowest temperature $\left(17^{\circ} \mathrm{C}\right)$ consistently inhibited ingestion and growth over the entire larval period. The estimate of the Arrhenius temperature (TA) was $11000 \mathrm{~K}$ for $\mathrm{C}$. gigas larvae. Larval development could be divided on the basis of feeding activity into an initial mixotrophic period with a lower and constant ingestion over the first days (from D- stage to early umbonate larva of $\approx 110 \mu \mathrm{m}$ length) followed by an exotrophic phase characterized by a sharp increase in ingestion (umbonate to eyed of $\approx 300 \mu \mathrm{m}$ length) and, finally, a third period for larvae $300 \mu \mathrm{m}$ during which ingestion decreased suddenly because of metamorphosis. Optimum larval development and settlement of the oyster $\mathrm{C}$. gigas occurred at $27^{\circ} \mathrm{C}$ and an increasing food supply as the larvae were growing. A food density of $\geq 20$ cells $\mu$ l-1 of T-ISO + CP or CG (1:1 cells number) in the culture water was required to maximise growth and metamorphosis success.
\end{abstract}

Keywords: Crassostrea gigas; Bivalve larvae; Ecophysiology; Growth; Food; Temperature 


\section{Introduction}

The Pacific oyster Crassostrea gigas (Thunberg) is the major commercial marine bivalve in French aquaculture and, to fulfil oyster farmers demand, spat production in hatcheries has become widespread (Ponis et al., 2006). The major objective in hatchery production is to improve larval survival by maximising larval growth and success at metamorphosis in the newly settled seed. Accordingly, the effects of environmental factors on larval physiology of $C$. gigas have to be investigated and specified. Among them, phytoplankton supply and temperature have been recurrently studied and considered as key factors affecting the physiological processes of oyster larvae of the genus Crassostrea (Helm and Millican, 1977; Gerdes, 1983; His et al., 1989; Abdel-Hamid et al., 1992; Mona et al., 1993; Lemos et al., 1994; Baldwin and Newell, 1995; Devakie and Ali, 2000).

Despite many studies on bivalve larval physiology, conflicting data have been reported. Great differences in experimental conditions can explain such divergence. Indeed, the influence of food levels on larval ingestion rates should be studied in a flow-through system where larval feeding activity can be measured under constant conditions over the whole rearing period (from D-stage to settlement). The use of a flow-through system avoids transfer and handling of larvae for measurements thus reducing stress on the organisms. Moreover, most ecophysiological studies on $C$. gigas larvae referred to a narrow experimental period of 7 to $10 \mathrm{~d}$ (Helm and Millican, 1977; Nascimento, 1980; Nell and Holliday, 1988; His et al., 1989; Abdel-Hamid et al., 1992; Mona et al., 1993). In contrast, the present work reports on physiological responses acquired over the complete larval period.

To provide basic information for larval ecophysiology research, we developed a flow-through rearing system allowing a constant flow of phytoplankton enriched seawater at desired temperatures as well as a hydrobiological data tracking system. This device avoids disturbance of the larvae throughout the rearing period and thus allows valid measurements.

The aim of this study was to investigate the effects of temperature and phytoplankton density on 1) feeding activity from D-stage to settlement 2) growth, and 3) metamorphosis of the Pacific oyster Crassostrea gigas larvae reared under constant experimental conditions.

\section{Materials and methods}

\subsection{Rearing and hydrobiological tracking system description}

Broodstock C. gigas were transferred from western Brittany (France) into the Ifremer experimental hatchery at Argenton (Brittany, France) and conditioned at $19^{\circ} \mathrm{C}$ for six weeks. Larvae used in all experiments were produced from gametes that were obtained by gonad stripping (3 males and 6 females). The fertilised eggs were incubated in $150 \mathrm{I}$ tanks using a static system and $1 \mu \mathrm{m}$ filtered seawater at $25^{\circ} \mathrm{C}$ and a salinity of 34 . Development to D-stage was complete after 2 days.

Experiments were carried out in a flow-through culture system (Rico-Villa et al., 2008) to maintain algal density and constant temperature conditions, as well as, to allow continuous hydrobiological data recording from culture tanks. The system consists of a set of 150 I cylindro-conical tanks. Outflow from each tank was discharged into a secondary tank from which seawater was pumped for the hydrobiological survey, and this reservoir was used to avoid any disturbance of the larval culture when seawater was sampled for environmental monitoring. An automated system directed tank outflows through a chamber that contained probes for measurements of temperature, salinity, $\mathrm{pH}$ and fluorescence. The electronic system allowed real time data acquisition, activation of floodgates and pump, storage and data transfer to a central database throughout the larval rearing period. The system required 200 min for a complete sampling cycle, and thus, each tank was surveyed 6 to 7 times per day. In this study, phytoplankton concentration and temperature were controlled in rearing tanks, while parameters, such as $\mathrm{pH}$ and salinity, were recorded but generally followed the variations of the seawater from the natural environment.

\subsection{Effects of food density}

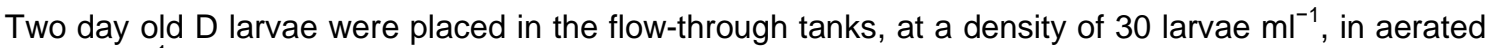
$\left(0.5 \mathrm{I} \mathrm{min}^{-1}\right) 1 \mu \mathrm{m}$ filtered seawater, at a mean salinity of 34.5. Water temperature was maintained at 
$25{ }^{\circ} \mathrm{C}$. Each experimental treatment consisted of two replicate tanks of larvae and an unstocked control tank with only constant flow of phytoplankton-enriched seawater.

Ration consisted of a binary diet (1:1 in cell numbers) of Isochrysis affinis galbana (T-ISO) and Chaetoceros calcitrans forma pumilum (CP, week 1) or C. gracilis (CG, from week 2) when the larvae were $\geq 110 \mu \mathrm{m}$ in size. Three phytoplankton densities were calculated to supply more phytoplankton than would be consumed by larvae allowing a permanent availability of remaining phytoplankton concentration of 12,20 and 40 cells $\mu{ }^{-1}$ around the larvae and equivalent to T-ISO + CP or CG in 1:1 in cell numbers (Table 1). An additional tank was continuously supplied with 1- $\mu \mathrm{m}$ filtered seawater at $25^{\circ} \mathrm{C}$ to measure the phytoplankton coming in from the environment despite seawater filtration. Tanks were drained and cleaned once a week to determine larval survival.

The feeding behaviour of $C$. gigas larvae can be divided into three different phases: mixotrophic, exotrophic and metamorphosis periods (Gerdes, 1983; Rico-Villa et al., 2006). To obtain the ingestion rate (IR) for larvae throughout these feeding periods, fluorescence values were analysed from the pumped seawater of each tank (test and control) at each phytoplankton concentration. Water samples of bispecific diet in control tanks were measured using an electronic particle counter (Multisizer III, equipped with a 100- $\mu \mathrm{m}$ aperture tube) and expressed as cells $\mu^{-1}$. These measurements were standardized to phytoplankton fluorescence values also recorded in control tanks to obtain a regression equation. This precaution was taken to remove any uncertainty of water samples contaminated by larval faeces in test tanks which should be analysed with a Multisizer counter but undetected using fluorescence measurements. IR was estimated following the equation: $I R=\left[\left(C_{c}-C_{t}\right)\right.$ $\left.{ }^{*} f\right] / n b$, where $C_{c}$ and $C_{t}$ are the phytoplankton densities (number of cells $\left.\mu\right|^{-1}$ ) in the control and test tanks respectively, $f$ is the water flow through each tank $\left(\mu \mathrm{d}^{-1}\right)$ and $n b$ is the number of larvae in the test tank. IR data was averaged and expressed as cells larvae ${ }^{-1} \mathrm{~d}^{-1}$. Moreover, IR at different algal cell densities was standardized to plot the relationship between food levels and IR in order to evaluate the feeding functional response of $C$. gigas larvae.

A $1 \mathrm{ml}$ sample was taken from each test tank to observe the larval development. A 5 I sample was taken every 2-3 days from each larval tank to measure shell length $(\mu \mathrm{m})$ and estimate larval growth. Shell length data were acquired using image analysis (Winlmager 2.0 and Imaq Vision Builder 6.0 software for image capture and analysis, respectively). The total number of larvae was determined once a week when tanks were drained individuals and the IR was corrected for larvae. When $\geq 50 \%$ of the population in a tank were eyed, plastic disks $(15 \mathrm{~cm}$ diameter) were placed in the tank as collectors. After four days, the percentage of metamorphosis was evaluated by counting the number of remaining larvae and subtracting from the total number of larvae initially stocked. An estimation of spat attached to collectors and tank walls was performed to confirm results.

\subsection{Effects of temperature}

A second set of experiments was carried out to test the influence of temperature on ingestion, growth and metamorphosis performance of $C$. gigas larvae. Two day old D larvae were distributed in 150-1 flow-through tanks at a density of 30 larvae $\mathrm{ml}^{-1}$ in $1 \mu \mathrm{m}$ filtered seawater at a mean salinity of 34.5 and at $0.5 \mathrm{I} \mathrm{min}^{-1}$ aeration.

As in experiment 1, larvae were fed a bispecific diet (1:1 in cells numbers) of T-ISO and CP (week 1) or CG (from week 2). Feeding depended on larval size (or biomass), beginning with a daily supply of 40 cells $\mu^{-1}$ and ending with 200 cells $\mu^{-1}$ of microalgae. This ration was calculated to provide more phytoplankton than would be consumed by larvae allowing a permanent availability of phytoplankton of 30 cells $\mu \mathrm{I}^{-1}$ of T-ISO + CP or CG around the larvae in order to sustain larval growth.

Five different temperatures were tested: 17, 22, 25, 27 and $32{ }^{\circ} \mathrm{C}$. Each experimental condition consisted of a test tank with larvae and a control tank with only constant flow of enriched phytoplankton seawater. This experiment was conducted twice to provide replication. D-stage larvae, initially reared at $25^{\circ} \mathrm{C}$, were adjusted to each temperature at a rate $0.5^{\circ} \mathrm{C} \mathrm{h}^{-1}$ and then allowed to acclimate for 1 day. Owing to a relative short larval life, a brief period for temperature acclimation was applied. At the beginning of the experiment larval survival was estimated and revaluated a week later to secure our approach. Shell length $(\mu \mathrm{m})$, growth rate $\left(\mu \mathrm{m} \mathrm{d}^{-1}\right)$, metamorphosis $(\%)$ and ingestion rate (cells larvae $\mathrm{e}^{-1} \mathrm{~d}^{-1}$ ) were calculated as described above (2.2) and the maximal ingestion rate reported here corresponded to mixotrophic and exotrophic periods at each temperature. The Arrhenius temperature $\left(T_{A}\right)$ was used to describe the effect of temperature on larval growth rates within the range of temperature (Kooijman, 2000). The Arrhenius temperature was estimated by means of a linear regression of the natural logarithmic of larval growth rates against the inverse absolute temperatures $\left(17,22,25,27\right.$ and $\left.32{ }^{\circ} \mathrm{C}\right)$ to obtain the slope $T_{A}$ of the linear graph. 


\subsection{Statistical analysis}

The results of two temperature effect trial were pooled $(n=2)$ for the purpose of statistical analysis to diminish errors associated with the repetitions in time. Percentage data was arcsine transformed prior to statistical analysis. Normality and homoscedasticity were tested using a Kolmogorov-Smirnov and Cochran test, respectively. One-way ANOVA was used to test the effects of temperature or food density and when significant differences were detected among means, a post hoc Scheffé's pairwise multiple comparison test was performed. The Statview ${ }^{\circledR} 5.0$ software package was used to perform these analyses. The significance level was set at $5 \%$.

\section{Results}

\subsection{Hydrobiological environment survey}

For both experiments seawater temperatures were stable and the averages remained within $0.2{ }^{\circ} \mathrm{C}$ of the desired experimental temperature. No fluorescence was recorded ( $0 \mathrm{FNU})$ in the additional tank. Seawater salinity and $\mathrm{pH}$ throughout the experiments were $34.0 \pm 0.5 \mathrm{psu}$ and $\mathrm{pH}=8.20 \pm 0.01$ respectively.

\subsection{Effects of food density}

At all food concentrations, mortality was very low throughout the experiment ( $\leq 10 \%)$. Increasing food density increased larval ingestion (Fig. 1). Larvae surrounded by phytoplankton at 20 and $40{\text { cells } \mu l^{-1}}^{-1}$ (1:1 cells of T-ISO + CP or CG ) showed three phases in their feeding activity throughout larval development. Low algal consumption (4000 to 8000 cells larvae $\mathrm{e}^{-1}$ ) characterised the first $5 \mathrm{~d}$ and corresponded to the mixotrophic period. Throughout the exotrophic period, ingestion increased markedly up to day 14 with values as high as 45000 to 55000 cells larvae ${ }^{-1}$. Then a drop in phytoplankton ingestion occurred during metamorphosis. Larvae surrounded by $12 \mathrm{cells}^{-1} \mathrm{l}^{-1}$ displayed a low ingestion over the whole rearing period with a maximum ingestion of 17000 cells larvae ${ }^{-1} \mathrm{~d}^{-1}$ (Fig. 1).

When plotting ingestion rate against food density a hyperbolic functional response was obtained (Fig. 2). Indeed the ingestion rate was linearly correlated to increasing food density up to a maximum of 25 cells $\mu l^{-1}$ corresponding to a maximal ingestion rate of 50000 cells larvae ${ }^{-1} \mathrm{~d}^{-1}$. This value remained rather constant when food density increased up to 45 cells $\mu^{-1}$.

Because a straight line relationship exists during the exotrophic period between larval growth (length) and food density the plotted slope was equivalent to the larval growth rates (Fig. 3). Overall larval growth increased with increasing algal density. For all treatments, the correlation coefficient value of fitted regression lines was high $\left(r^{2} \geq 0.97\right)$. A constant availability of 20 and 40 cells $\mu l^{-1}$ around the larvae allowed the highest growth rates with no significant differences between both values $(17.07 \pm$ 2.52 and $19.55 \pm 2.63 \mu \mathrm{m} \mathrm{d}^{-1}$, respectively) while a concentration of $12 \mathrm{cells} \mathrm{I}^{-1}$ around the larvae led to the lowest growth rates $\left(11.87 \pm 1.97 \mu \mathrm{m} \mathrm{d}^{-1}\right)$, significantly different from the others (Fig. 3).

In all treatments the first competent eyed larvae were observed on day 16 . Food density affected metamorphosis. A supply of 12 cells $\mu^{-1}$ around larvae produced significantly lower metamorphosis $(25.5 \pm 5.3 \%)$ while larvae supplied 20 and 40 cells $\mu l^{-1}$ metamorphosed at $44( \pm 5.4 \%)$ and $40( \pm$ $2.1 \%)$ respectively with no significant difference between treatments.

\subsection{Effects of temperature}

On day 2 , at the end of the temperature acclimation period, low larval mortalities $(\leq 2 \%)$ were recorded and confirmed on day 7 after the first draining of the test tank volume. At the end of the experiment mortality was $\leq 10 \%$ within the temperature range from 22 to $32{ }^{\circ} \mathrm{C}$ and $\leq 20 \%$ at $17^{\circ} \mathrm{C}$.

Temperature strongly influenced larval feeding activity. As a general pattern, the consumption by larvae was low during the first days of rearing corresponding to the mixotrophic period for D-stage larvae. When larvae became umbonate, ingestion increased and peaked for eyed during the exotrophic period. Thereafter, ingestion decreased to metamorphosis. According to this feeding pattern, there were differences in the maximal ingestion rate reached by larvae during mixotrophic and 
exotrophic periods at each temperature (Table 2). The mixotrophic period lasted $5 \mathrm{~d}$ for larvae reared from 22 and $32{ }^{\circ} \mathrm{C}$. Over this period there were significant differences in maximal ingestion rate and a test of pairwise multiple comparison pointed out two homogenous groups: one for larvae reared at 27 and $32{ }^{\circ} \mathrm{C}$ with 7700 and 8200 cells larvae ${ }^{-1} \mathrm{~d}^{-1}$ respectively and a second one for those reared at 22 and $25^{\circ} \mathrm{C}$ with 4000 and 5400 cells larvae ${ }^{-1} \mathrm{~d}^{-1}$ respectively. With regard to the lowest temperature, the mixotrophic period extended to $10 \mathrm{~d}$ at $17^{\circ} \mathrm{C}$ with a maximal ingestion rate of 3100 cells larvae ${ }^{-1} \mathrm{~d}^{-}$

${ }^{1}$. The exotrophic period varied with temperature. It extended to day 12 at 27 and $32{ }^{\circ} \mathrm{C}$ and was characterized by the highest ingestion rates ( 55200 and 64500 cells larvae ${ }^{-1} \mathrm{~d}^{-1}$, respectively). At 25 ${ }^{\circ} \mathrm{C}$, the exotrophic period extended to day 16 with a maximal ingestion rate of 41900 cells larvae ${ }^{-1} \mathrm{~d}^{-1}$ while at $22^{\circ} \mathrm{C}$ this value reached 51500 cells larvae $e^{-1} \mathrm{~d}^{-1}$, albeit $5 \mathrm{~d}$ later, on day 21 . Lastly, larvae reared at $17^{\circ} \mathrm{C}$ exhibited the lowest ingestion over the exotrophic period with a maximal ingestion rate of 38300 cells larvae ${ }^{-1} d^{-1}$, on day 32 .

Based on feeding activity, larvae exhibited a high ingestion rate during the exotrophic period and, accordingly, a more precise linear relationship with growth could be achieved when only larvae from $100 \mu \mathrm{m}$ up to $280 \mu \mathrm{m}$ were considered. Thus, for each temperature, we expressed larval growth during exotrophic period (Fig. 4) during which a linear relation with temperature was found with high correlation coefficient values of fitted regression lines $\left(r^{2} \geq 0.95\right)$. Larval growth $\left(\mu \mathrm{m} \mathrm{d}^{-1} \pm S D\right)$ increased with increasing water temperatures $(F=385.67 ;$ df $4 ; P<0.0001): 5.95 \pm 1.53,11.41 \pm 2.17,15.99 \pm$ $2.48,19.31 \pm 2.37,19.95 \pm 3.11$ at $17,22,25,27$ and $32^{\circ} \mathrm{C}$ respectively (Fig. 4). Nevertheless, no significant differences between 27 and $32{ }^{\circ} \mathrm{C}$ were found by pairwise test comparison despite an artefact on day 13 with a slight decrease of larval growth at $32^{\circ} \mathrm{C}$, probably due to early settlement of the largest larvae. In contrast, pairwise test comparison revealed significant differences in larval growth at 22 and $25^{\circ} \mathrm{C}$ while lowest growth occurred at $17{ }^{\circ} \mathrm{C}$. When growth data were reanalysed at different temperatures, as an Arrhenius plot, the linear relationship was fitted and the estimate of the Arrhenius temperature $\left(T_{A}\right)$ was $11000 \pm 2500 \mathrm{~K}\left(r^{2}=0.97\right)$.

Success at metamorphosis followed a similar trend as for growth with highest settlement at 27 and 32 ${ }^{\circ} \mathrm{C}$ (87 and 86\% respectively) achieved in less than $15 \mathrm{~d}$ with detection of eyed larvae from day 11. Larvae reared at 22 and $25{ }^{\circ} \mathrm{C}$ led to similar settlement (55 \pm 8 and $58 \pm 10 \%$, respectively) but delayed at $22^{\circ} \mathrm{C}$ on day 25 (vs. day 20 at $25^{\circ} \mathrm{C}$ ). The temperature of $17{ }^{\circ} \mathrm{C}$ led to the lowest settlement $(16 \pm 3 \%)$, which only occurred on day 35 .

\section{Discussion}

\subsection{Effects of food density}

This study suggests that larval algal consumption varies with larval size in order to sustain growth and metamorphosis. Food ration remained within a broad range of a phytoplankton supply from 30 cells $^{-1}$ ${ }^{1}$ to 300 cells $\mathrm{I}^{-1}$ throughout larval rearing in order to maintain a fixed algal density around the larvae by means of a flow-through rearing system. In these conditions, our experiments were accordingly carried out under constant food level and allowed the set up of a long-term physiological response (larval ingestion rate).

Larvae surrounded by 20 and 40 cells $\mu^{-1}$ exhibited three feeding phases during development. A low but progressive increase in consumption was noted from D-stage veliger to early umbonate larvae (phase 1). During phase 2, microalgae ingestion increased sharply from umbonate to eyed larvae, until a sudden decrease was noted approaching metamorphosis (phase 3 ). The feeding pattern during the mixotrophic phase may be related to the incomplete development of the digestive system in larvae. Gallager (1988) stated that young bivalve larvae $(\leq 100 \mu \mathrm{m}$ length shell) have a narrow oesophagus and a gut volume that may limit the size and number of particles ingested. During this phase, metabolism is supported by the reserve material provided in the eggs (Bayne, 1983).

In this study, C. gigas larvae started the exotrophic stage (phase 2) with an ingestion rate increase when they measured $\approx 100-110 \mu \mathrm{m}$. This ingestion capability may be linked to the development of the velar ciliary tracts (Strathmann, 1978) allowing the larva to trap particles, transport them through the food groove and ingest them in an efficient manner. This feeding behaviour shows that larval rearing for the first few days may occur with a low food supply but when larvae initiate strict exogenous feeding (from days 5 to 6 in the present study) the amount of food becomes an essential factor in their successful development. One aim for the larvae during the exotrophic stage is the accumulation of sufficient reserves to allow them to meet the energy demands during the process of metamorphosis (phase 3) and ensure their capacity for survival (Haws et al., 1993). In this way, the viability of larvae, before metamorphosis, depends on both accumulation and utilisation of energy substrates, mainly 
related to catabolism of proteins and lipids (Bartlett, 1979; Laing and Earl, 1998; Moran and Manahan, 2004). When the larvae undergo the process of metamorphosis, their feeding pattern is altered because behavioural and morphological processes take place. Indeed, movement and feeding are inhibited because the velum is absorbed and replaced with the branchia (Cannuel and Beninger, 2006). Moreover, late pediveliger larvae increase crawling behaviour in search of a suitable substratum for metamorphosis. Therefore, a temporary stop in the ingestion is not surprising and because this event is not synchronous in the whole larval population the mean ingestion rate decreased at the end of the larval life.

Our results show that $C$. gigas ingestion activity was also linearly related to food density up to a threshold level above which ingestion remains fairly constant. This feeding behaviour can be compared to food densities to assess the functional response (Holling, 1959). An alternative pattern to describe the relationship between food density and larval ingestion rates in this study appeared to be consistent with a hyperbolic function. This function model establishing that ingestion rate is food dependant up to a plateau has also been reported for C. virginica (Baldwin and Newell, 1995).

In the present study ingestion rate increased parallel to food density up to a saturation level. Such a pattern is in agreement with other studies on bivalve larvae exposed to a microalgae supply gradient. Nevertheless, the saturation level is species specific. Gallager (1988) for Mercenaria mercenaria, MacDonald (1988) for Patinopecten yessoensis and Baldwin and Newell (1995) for C. virginica obtained such saturation of ingestion at relatively low concentrations of food ranging from 10 to 40 cells $\mu l^{-1}$ with the same microalgae T-ISO. In contrast, Crisp et al. (1985) for Ostrea edulis and PérezCamacho et al. (1994) for $R$. decussatus reported that such saturation occurred at higher concentrations from 200 to 250 cells $\mu^{-1}$ using Pavlova lutheri or Isochrysis galbana as food supply. Differences in food level saturation between species suggest that larvae may differ in energy acquisition and utilization. Moreover, these variations should also be related to rearing conditions (e.g. flow-through system or larval density). Nevertheless, our results show that saturation for $C$. gigas larvae occurred at higher concentrations equivalent to a residual phytoplankton of 20 cells $\mu^{-1}$. At the same time, food supply was increased in a range of 60 to 260 cells $\mu l^{-1}$ as larvae grew to avoid competition for food between larvae and maximise increase in biomass through the whole larval rearing (Table 1). Considering this feature, maximal ingestion was reached on day 14 for a supply of 260 cells $\left.\mu\right|^{-1}$.

The functional response demonstrated that $C$. gigas larvae achieved the maximal ingestion rate for 50 000 cells larvae ${ }^{-1}$ day $^{-1}$. In a similar context, Baldwin and Newell (1995) reported that maximal ingestion rate of $C$. virginica larvae, expressed in cell volume concentration, was equal to $2.2 \times 10^{6}$ $\mu \mathrm{m}^{3} \mathrm{~d}^{-1}$ larva ${ }^{-1}$ of $200 \mu \mathrm{m}$ length when fed natural phytoplankton. When our data are converted in cell volume, based on measurement of bispecific microalgae sample (mean value of $48 \mu^{3}$ ) we obtained a similar maximal ingestion rate of $2.4 \times 10^{6}{\mu \mathrm{m}^{3}}$ larva $^{-1} \mathrm{~d}^{-1}$. This similarity suggests that larvae can control their feeding patterns and respond in this way to reach their maximal ingestion as long as nutritional quality is achieved because natural phytoplankton might be nutritionally comparable to cultured food (bispecific diet) used in the present study.

On the other hand, the growth rate was directly correlated to the amount of food delivered as larvae grew. This study points out that the maximal growth rate occurred when larvae were surrounded by 40 cells $\mu^{-1}$ but did not differ statistically when larvae were surrounded by 20 cells $\mu^{-1}$. In this way, the food ration meeting this requirement corresponds to maximal ingestion rate, which was achieved from 20 cells $\mu \mu^{-1}$. To corroborate the feeding behaviour of $C$. gigas larvae it would be interesting to experiment on lower $\left(\leq 5\right.$ cells $\left.\mu l^{-1}\right)$ and higher $\left(\geq 50\right.$ cells $\left.\mu l^{-1}\right)$ phytoplankton densities surrounding larvae despite present evidence.

On the other hand, metamorphosis performances have been reported here because this is important from an aquaculture standpoint. In the present work, larvae settled at their convenience without either size selection or metamorphosis induction. When phytoplankton concentrations were maintained at 20 and 40 cells $\mu^{-1}, 40$ to $44 \%$ of newly settled spat were detected $5 \mathrm{~d}$ after the onset of metamorphosis but it has to be considered that the remaining population of larvae was competent to metamorphose and mortality was $\leq 10 \%$ at the end of the experiment.

\subsection{Effects of temperature}

The results of the present study indicated that temperature greatly influenced ingestion, growth and metamorphosis of $C$. gigas larvae. Increased ingestion was recorded as temperature increased resulting in higher growth throughout larval development. Similar observations were reported by Beiras et al. (1994) on Ruditapes decussatus larvae. Our work however is the first report of feeding 
activity over an entire larval life cycle including metamorphosis of C. gigas over a range of temperatures $\left(17\right.$ to $\left.32{ }^{\circ} \mathrm{C}\right)$.

Gerdes (1983) was the first author to report in detail ecophysiological data on C. gigas larvae, however working with a single temperature $\left(25^{\circ} \mathrm{C}\right.$ ) and using a different technical approach (closed rearing system). Moreover, the food supply was constant during his experiments and thus he did not take into account larval biomass increase. Lastly his results were tainted with high variability of ingestion measurements which may be explained by variations in food concentration surrounding the larvae. Under these conditions it is not surprising that our results diverged from those reported by Gerdes (1983) who found higher ingestion rates for larvae.

In our work a sustained response in ingestion activity within a wide range of temperature was possible by using an efficient flow-through rearing system, which supplied food in an abundant and reliable way to allow an adequate food uptake. A feeding response to temperature range, even at higher temperatures, was achievable because, in the one hand, food was provided in abundance to supply more microalgae than larvae would feed. On the other hand, the integrity of phytoplankton cells used in the present study when exposed to a wide range of temperatures (17 to $32^{\circ} \mathrm{C}$ ) guaranteed the availability of the food delivered to the larvae. Lastly such a technical approach allowed a constant seawater renewal during the whole experimental period, thus avoiding deposition of algal cells at high temperatures and accordingly the occurrence of bacteria bloom due to larval metabolites and degradation of phytoplankton. This has been reported to be a recurrent problem in previous studies on bivalve larvae (Helm and Millican, 1977; Hrs-Brenko, 1981; Lemos et al., 1994). The ingestion activity increase with temperature suggests a thermal acclimation strategy for larvae to fulfil their energetic requirements. This biological strategy may be related to an enhancement in cilia activity for feeding and catalytic activity of digestive enzymes to offset thermal stress and regulate the metabolism of larvae.

This study showed undoubtedly the high tolerance of $C$. gigas larvae (17 to $32{ }^{\circ} \mathrm{C}$ ) expressed with a high value of Arrhenius temperature $(11000 \mathrm{~K})$. Previous studies on others bivalve larvae reported an Arrhenius relationship of $8460 \mathrm{~K}$ for Mytilus edulis (Sprung, 1984 cited in Kooijman, 2000) and $7596 \mathrm{~K}$ for Macoma balthica (Bos et al., 2006). Although these experiments were carried out within a smaller range of temperatures $\left(7\right.$ to $\left.17^{\circ} \mathrm{C}\right)$ they showed a lower thermal tolerance for these species. Our data suggest an ability to adjust physiological rates to confront environmental temperature change within the range of relevant temperatures and upper and lower non lethal margins. Moreover, this broad tolerance range of temperature might explain the cosmopolitan distribution of C. gigas among subtropical and temperate areas (Goulletquer et al., 1999; Langdon et al., 2003; Sicard et al., 2006) and its progressive geographical extension in new environments (Diederich et al., 2005) since their larvae are able to tolerate temperate $\left(17^{\circ} \mathrm{C}\right)$ to warm $\left(32^{\circ} \mathrm{C}\right)$ seawater temperatures.

Results from the present study confirmed that $C$. gigas larval growth increases markedly with increasing temperature as previously reported in the literature (Helm and Millican, 1977; His et al., 1989; Abdel-Hamid et al., 1992). C. gigas larvae proved to be an eurythermic stage within a wide temperature range as demonstrated in adult stage (Sicard et al., 2006), but with a marked thermodependency between 22 and $32{ }^{\circ} \mathrm{C}$. Within this range, the optimal temperature expressed as maximum growth rates occurred at $32{ }^{\circ} \mathrm{C}$ but did not differ significantly at $27{ }^{\circ} \mathrm{C}$. Moreover, at both temperatures low mortalities $(\leq 10 \%)$ were displayed at the end of the experiments. Therefore the present data showed that a physiological response was achievable even at the highest temperature, which demonstrated that $32{ }^{\circ} \mathrm{C}$ is not the upper thermal limit for $C$. gigas during its larval stage. On that count our results are conflicting with those of Helm and Millican (1977) who reported high mortalities $(65 \%)$ at $32^{\circ} \mathrm{C}$. This sensibility to such a temperature has been also reported for C. gigas juveniles (Flores-Vergara et al., 2004) and adults (Bougrier et al., 1995) with mortalities $\geq 40 \%$. Complementary experiments should be accordingly carried out to determine the upper thermal boundary of $C$. gigas larvae with temperature $\geq 33^{\circ} \mathrm{C}$. Thus, growth of $C$. virginica larvae is reduced at $33{ }^{\circ} \mathrm{C}$ and massive death occurred at $35{ }^{\circ} \mathrm{C}$ (Davis and Calabrese, 1964). The lowest temperature applied in the present study $\left(17^{\circ} \mathrm{C}\right)$ caused no other apparent damage than a significant reduction of larval growth, mortalities being $\leq 20 \%$ after one month of rearing. The failure of the larvae to grow at low temperature may be due to their inability to digest ingested microalgae despite food availability (Manoj and Appukuttan, 2003). His et al. (1989) reported that $C$. gigas larvae can survive at $15^{\circ} \mathrm{C}$ but their experiments lasted only one week. The present study suggests that at such a temperature the larvae may still have been in the mixotrophic phase at the end of their experiment and therefore it is not surprising that survival was high.

Concerning metamorphosis, a positive relation can be drawn with increase in temperature, which is in agreement with previous observations on Saccostrea glomerata (Dove and O'Connor, 2007) with an optimal temperature at $30^{\circ} \mathrm{C}$. According to Bayne (1983), larvae delay metamorphosis at low 
temperatures for longer periods than at high temperatures and the duration of the free swimming larval period is accordingly prolonged. Our data showed that larvae reared at $17^{\circ} \mathrm{C}$ initiated settlement on day 31 but only a small fraction of the population was concerned (16\%). This result demonstrates that $17^{\circ} \mathrm{C}$ could be considered as an impractical temperature for $C$. gigas commercial hatchery from an economic standpoint. In contrast, $27^{\circ} \mathrm{C}$ led to the best growth $\left(19.31 \mu \mathrm{m} \mathrm{d}^{-1}\right)$ and highest settlement $(87 \%)$ in less than two weeks (no significant differences at $32^{\circ} \mathrm{C}$ ). This temperature is accordingly recommended for Pacific oyster hatchery production but great caution is required to fulfil the larval feeding requirements and to limit bacterial proliferation. The use of flow-through rearing techniques should overcome both constraints. Lastly, in such systems, C. gigas larval performances are reproducible because for similar food supply (20 cells. $\mu^{-1}$ around larvae) and temperature $\left(25^{\circ} \mathrm{C}\right.$ ) growth and settlement in exp. 1 were $17 \mu \mathrm{m} \mathrm{d}^{-1}$ and $44 \pm 5 \%$ vs. $16 \mu \mathrm{m} \mathrm{d}^{-1}$ and $58 \pm 10 \%$ in exp. 2.

\section{Acknowledgements}

The first author was funded by a scholarship from the Consejo Nacional de Ciencia y Tecnologia (CONACyT) Mexico. Special thanks to Christian Mingant, Isabelle Quéau and Pierrick Le Souchu from Station Expérimentale d'Argenton Ifremer for their technical help in the hatchery. The authors are also grateful to Henry Kaspar for improving the first English version manuscript and to an anonymous reviewer for the final edition. 


\section{Tables}

Table 1

Daily food ration (cells $\mu l^{-1}$ ) related to larval age over the whole rearing period during the experiment on food concentration effects. This supply concentration allows a permanent phytoplankton density of 12, 20 and 40 cells $\mu^{-1}$ around the larvae respectively (1:1 in cells number of T-ISO + CP or CG). See Fig. 3 for correspondence between larval age and larval size for each phytoplankton density.

\begin{tabular}{|c|c|c|c|c|c|c|c|c|c|}
\hline $\begin{array}{c}\text { Age of larvae } \\
\text { (day) }\end{array}$ & $2-5$ & 6 & $7-9$ & 10 & $11-12$ & $13-15$ & $16-17$ & $18-19$ & $20-21$ \\
\hline $12{\text { cells }\left.\mu\right|^{-1}}^{1}$ & 30 & 40 & 50 & 70 & 80 & 100 & 150 & 120 & 100 \\
\hline 20 cells $\left.\mu\right|^{-1}$ & 60 & 70 & 100 & 130 & 160 & 260 & 260 & 200 & 170 \\
\hline $\begin{array}{l}\text { 4.2.1. } 40 \text { cells } \\
\mu l^{-1}\end{array}$ & 90 & 100 & 140 & 160 & 210 & 300 & 300 & 220 & 200 \\
\hline
\end{tabular}




\section{Table 2}

Effects of temperature on the maximal ingestion rate (mean $\pm \mathrm{SD} ; n=6-7$ measurements) expressed in $10^{3}$ cells larvae ${ }^{-1}$ day $^{-1}$ and recorded during mixotrophic and exotrophic periods. Numbers in brackets below indicate the duration in days of each feeding period. Larvae were surrounded by 30 cells $\mu \mathrm{I}^{-1}$ of T-ISO + CP or CG (1:1 in cells number).

\begin{tabular}{ccc}
\hline $\begin{array}{c}\text { Temperature } \\
\left({ }^{\circ} \mathrm{C}\right)\end{array}$ & $\begin{array}{c}\text { Mixotrophic } \\
\text { period }\end{array}$ & $\begin{array}{c}\text { Exotrophic } \\
\text { period }\end{array}$ \\
\hline \multirow{2}{*}{17} & $3.1 \pm 0.2^{\mathrm{a}}$ & $38.3 \pm 0.3^{\mathrm{a}}$ \\
& $(2-10)$ & $(11-32)$ \\
22 & $4.0 \pm 0.2^{\mathrm{b}}$ & $51.5 \pm 0.8^{\mathrm{b}}$ \\
& $(2-5)$ & $(6-21)$ \\
25 & $5.4 \pm 0.4^{\mathrm{b}}$ & $41.9 \pm 0.6^{\mathrm{c}}$ \\
& $(2-5)$ & $(6-16)$ \\
27 & $7.7 \pm 0.3^{\mathrm{c}}$ & $55.2 \pm 0.6^{\mathrm{d}}$ \\
& $(2-5)$ & $(6-12)$ \\
32 & $8.2 \pm 0.4^{\mathrm{c}}$ & $64.5 \pm 0.9^{\mathrm{d}}$ \\
& $(2-5)$ & $(6-12)$ \\
\hline
\end{tabular}

Different superscript letters indicate a significant difference $(P<0.05)$. 


\section{Figures}

\section{Fig. 1.}

Ingestion rate (IR in $10^{3}$ cells larvae ${ }^{-1}$ day $^{-1}$ ) of $C$. gigas larvae, reared at $25^{\circ} \mathrm{C}$, surrounded by three different phytoplankton densities. Each point represents daily mean \pm SD ( $n=6-7$ measurements).

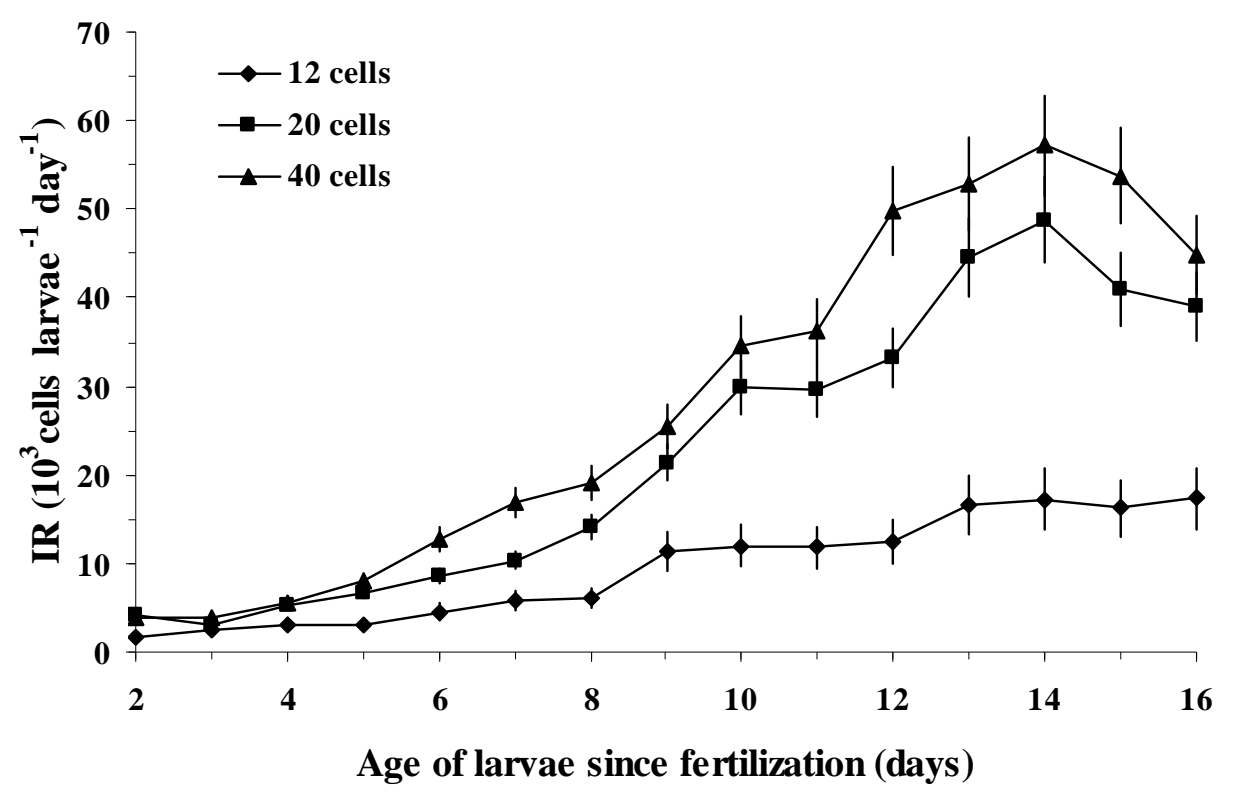


Fig. 2.

Functional response $\left(10^{3}\right.$ cells larvae $e^{-1}$ day $\left.^{-1}\right)$ of $C$. gigas larvae, reared at $25^{\circ} \mathrm{C}$, surrounded by different phytoplankton densities $\left(7.5-45\right.$ cells $\left.\mu^{-1}\right)$. Values are means $(n=10) \pm$ SD.

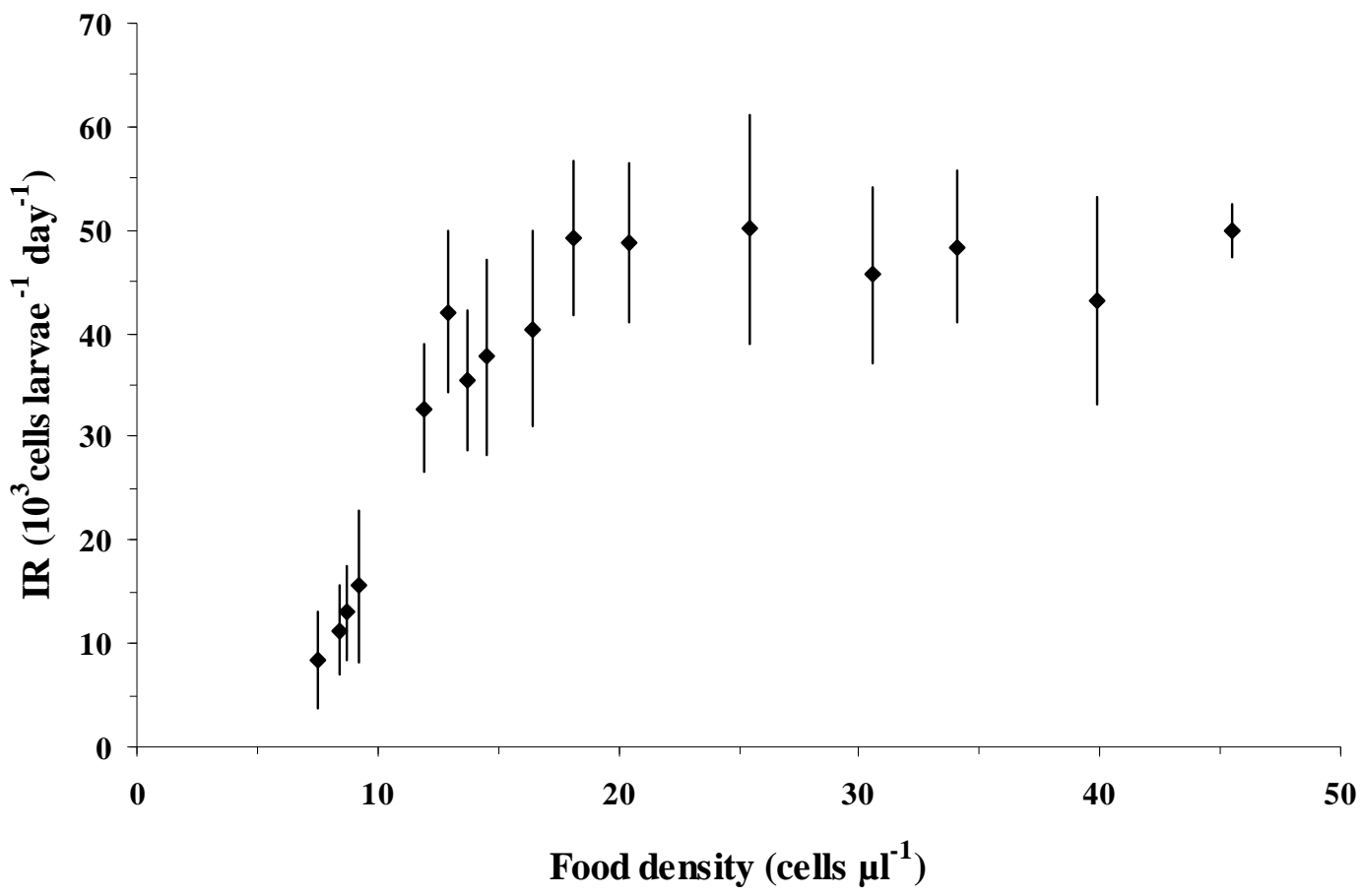


Fig. 3.

Larval growth (mean $\pm \mathrm{SD} ; n \geq 200$ ) of $C$. gigas larvae, reared at $25^{\circ} \mathrm{C}$, surrounded by three different phytoplankton densities (cells $\mu^{-1}$ ). Dashed lines correspond to the mixotrophic period while plain lines represent the exotrophic phase. $\mathrm{GR}=$ Larval growth rates $\left(\mu \mathrm{m}\right.$ day $\left.^{-1}\right)$ were estimated for the exotrophic period only (day 5-14).

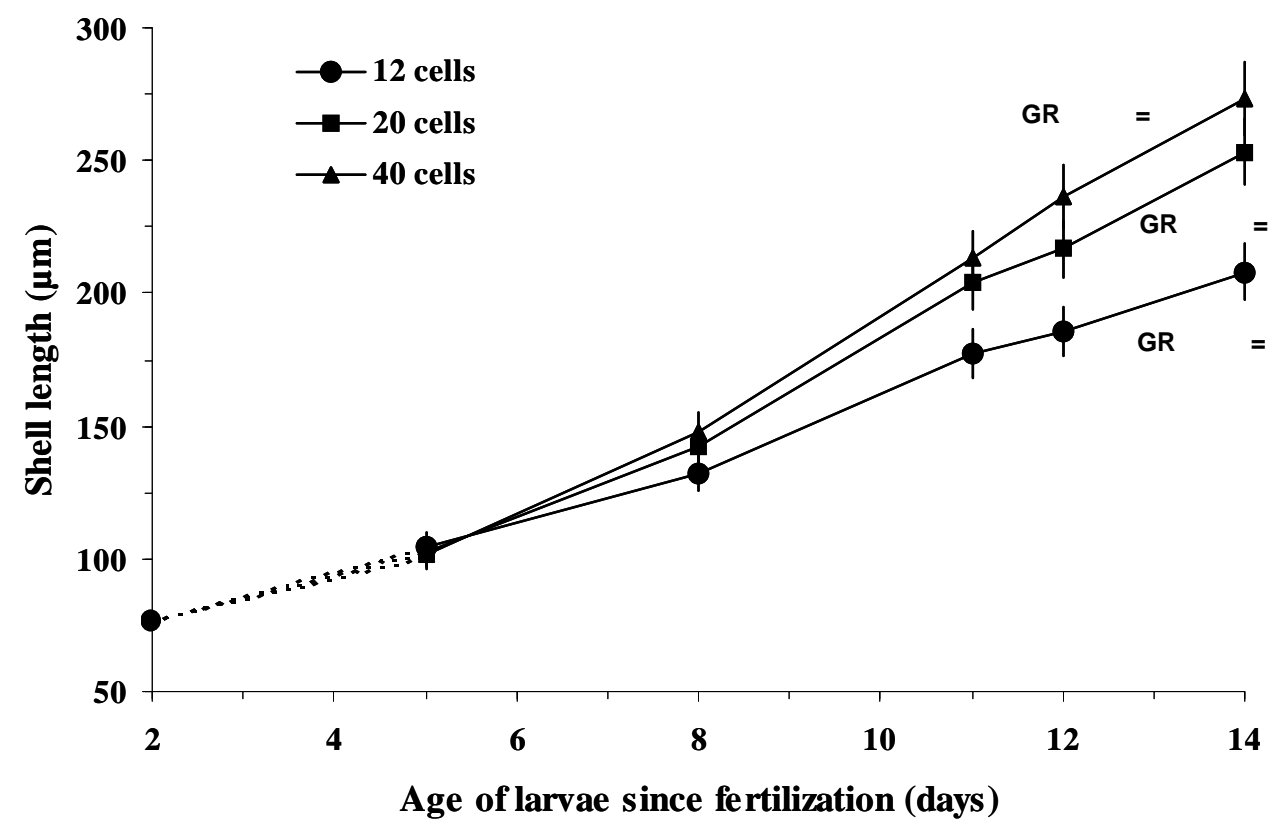


Fig. 4.

Larval growth (mean $\pm \mathrm{SD} ; n \geq 200$ ) of $C$. gigas, surrounded by 30 cells $\mu \mathrm{I}^{-1}$ and reared at five temperatures. Dashed lines correspond to the mixotrophic period while plain lines represent the exotrophic phase. $G R=$ Larval growth rates $\left(\mu \mathrm{m}_{\text {day }}{ }^{-1}\right)$ were calculated for the exotrophic period only.

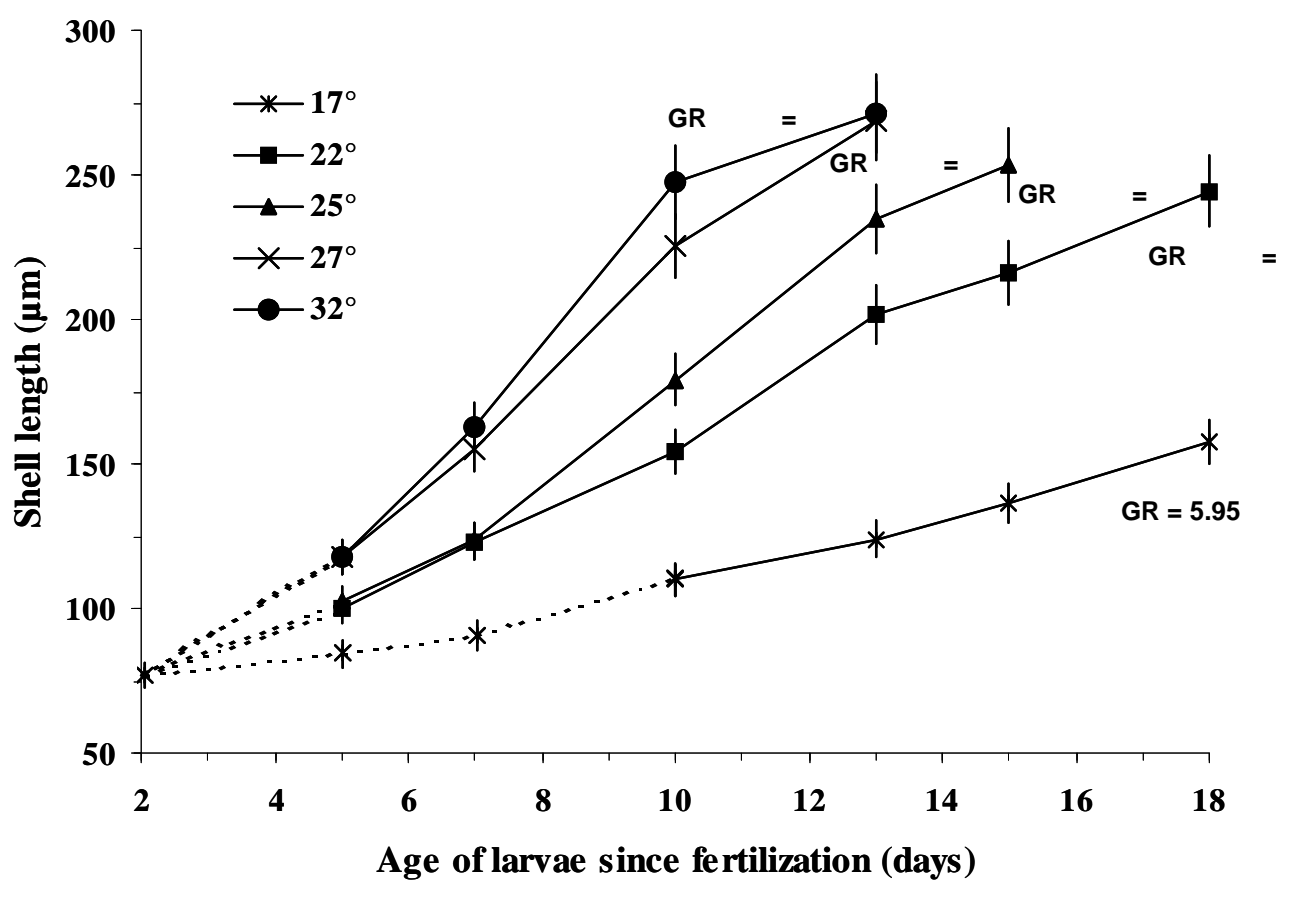




\section{References}

Abdel-Hamid, M.E., Mona, M.H., Khalil, A.M., 1992. Effects of temperature, food and food concentrations on the growth of the larvae and spat of the edible oyster Crassostrea gigas (Thunberg). J. Mar. Biol. Assoc. India 34(1\&2), 195-202.

Baldwin, B.S., Newell, R.I.E., 1995. Feeding rate responses of oyster larvae (Crassostrea virginica) to seston quantity and composition. J. Exp. Mar. Biol. Ecol. 189, 77-91.

Bartlett, B.R., 1979. Biochemical changes in the Pacific oyster, Crassostrea gigas (Thunberg, 1795) during larval development and metamorphosis. Proc. Nat. Shellfish. Assoc. 69, 202.

Bayne, B.L., 1983. Physiological ecology of marine molluscan larvae. In: N.H. Verdonk (Eds.), The Mollusca, vol. III, Academic Press, New York. pp. 299-343.

Beiras, R., Perez-Camacho, A., 1994. Influenced of food concentration on the physiological energetics and growth of Ostrea edulis. Mar. Biol. 120, 427-435.

Bos, O. G., Hendriks, I. E., Strasser, M., Dolmer, P., Kamermans, P., 2006. Estimation of food limitation of bivalve larvae in coastal waters of north-western Europe. J. Sea Res. 55(3), 191-206.

Bougrier, S., Geairon, P., Deslous-Paoli, J.M., Bather, C., Jonquières, G., 1995. Allometric relationships and effects of temperature on clearance and oxygen consumption rates of Crassostrea gigas (Thunberg). Aquaculture 134, 143-154.

Cannuel, R., Beninger, P., 2006. Gill development, functional and evolutionary implications in the Pacific oyster Crassostrea gigas (Bivalvia: Ostreidae). Mar. Biol. 149, 547-563.

Crisp, D.J., Yule, A.B., White, K.N., 1985. Feeding by oyster larvae: The functional response, energy budget and a comparison with mussel larvae. J. Mar. Biol. Assoc. UK 65(3), 759-783.

Davis, H.C., Calabrese, A., 1964. Combined effects of temperature and salinity on development of eggs and growth of larvae of M. mercenaria and C. virginica. Fish. B. 63, 643-655.

Devakie, M.N., Ali, A.B., 2000. Salinity-temperature and nutritional effects on the setting rate of larvae of the tropical oyster, Crassostrea iredalei (Faustino). Aquaculture 184, 105-114.

Diederich, S., Nehls, G., van Beusekom, J.E.E., Reise, K., 2005. Introduced Pacific oysters (Crassostrea gigas) in the northern Wadden Sea: invasion accelerated by warm summers? Helgoland Mar. Res. 59, 97-106.

Dove, M.C., O'Connor, W.A., 2007. Salinity and temperature tolerance of Sydney rock oysters Saccostrea glomerata during early ontogeny. J. Shellfish Res. 26, 939-947.

Flores-Vergara, C., Cordero-Esquivel, B., Cerón-Ortiz, A.N., Arredondo-Vega, B.O., 2004. Combined effects of temperature and diet on growth and biochemical composition of the Pacific oyster Crassostrea gigas (Thunberg) spat. Aquac. Res. 35, 1131-1140.

Gallager, S.M., 1988. Visual observations of particle manipulation during feeding in larvae of a bivalve mollusk. Bull. Mar. Sci. 43(3), 344-365.

Gerdes, D., 1983. The Pacific oyster Crassostrea gigas. Part I. Feeding behavior of larvae and adults. Aquaculture 31, 195-219.

Goulletquer, P., Wolowicz, M., Latala, A., Gearion, P., Huvet, A., Boudry, P., 1999. Comparative analysis of oxygen consumption rates between, cupped oyster spat of Crassostrea gigas of French, Japanese, Spanish and Taiwanese origins. Aquat. Living Resour. 12(4), 271-277. 
Haws, M.C., DiMichele L., Hand S.C., 1993. Biochemical changes and mortality during metamorphosis of the Eastern oyster Crassostrea virginica and the Pacific oyster Crassostrea gigas. Mol. Mar. Biol. Biotechnol. 2, 207-217.

Helm, M.M., Millican P.F., 1977. Experiments in the hatchery of Pacific oyster (Crassostrea gigas Thunberg). Aquaculture 11, 1-12.

His, E., Robert, R., Dinet, A., 1989. Combined effects of temperature and salinity on fed and starved larvae of the Mediterranean mussel, Mytilus galloprovincialis and the Japanese oyster Crassostrea gigas. Mar. Biol. 100, 455-463.

Holling, C.S., 1959. Some characteristics of simple types of predation and parasitism. Can. Entomol. 91, 824-839.

Hrs-Brenko, M., 1981. The growth and survival of larvae of several bivalve species at high temperatures and the practicability of their culture in heated effluent waters. Acta Biologica lugoslavica. Ichthyologia 13, 29-37.

Kooijman, S. A. L. M., 2000. Dynamic Energy and Mass Budgets in Biological Systems. Cambridge University Press. 424 pp.

Laing, I., Earl, N.H., 1998. The lipid content, spatfall and subsequent growth of early and late settling hatchery-reared Pacific oyster, Crassostrea gigas Thunberg, larvae. Aquac. Res. 29, 19-25.

Langdon, C., Evans, F. Jacobson, D., Blouin, M., 2003. Improved family yields of Pacific oyster Crassostrea gigas (Thunberg) derived from selected parents. Aquaculture 220, 227-244.

Lemos, M.B.N., Nascimento, I.A., De Araujo, M.M.S., Pereira, S.A., Bahia, I., Smith, D.H., 1994. The combined effects of salinity, temperature, antibiotics and aeration on larval growth and survival of the mangrove oyster, Crassostrea rhizophorae. J. Shellfish Res. 13, 187-192.

MacDonald, B.A., 1988. Physiological energetic of Japanese scallop Patinopecten yessoensis larvae. J. Exp. Mar. Biol. Ecol. 120, 155-170.

Manoj, N.R., Appukuttan, K.K., 2003. Effect of temperature on the development, growth, survival and settlement of green mussel Perna viridis (Linnaeus, 1758). Aquac. Res. 34, 1037-1045.

Mona, M.H., Abdel Hamid, M.E., Khalil, A.M., 1993. Oxygen consumption rate as a function of temperature and starvation of the veligers of edible oyster Crassostrea gigas (Thunberg). J. Mar. Biol. Assoc. India 35(1\&2), 24-28.

Moran, A.L., Manahan, D.T., 2004. Physiological recovery from prolonged 'starvation' in larvae of the Pacific oyster Crassostrea gigas. J. Exp. Mar. Biol. Ecol. 306, 17-36.

Nascimento, I.A., 1980. Growth of the larvae of Crassostrea gigas Thunberg, fed with different algal species at high cell concentrations. J. Cons. Int. Explor. Mer. 39(2), 134-139.

Nell, J.A., Holliday, J.E., 1988. Effects of salinity on the growth and survival of Sydney rock oyster (Saccostrea commercialis) and Pacific oyster (Crassostrea gigas) larvae and spat. Aquaculture 68, 39-44.

Pérez-Camacho, A., Beiras, R., Albentosa, M., 1994. Effects of algal food concentration and body size on the ingestion rates of Ruditapes decussatus (Bivalvia) veliger larvae. Mar. Ecol. Prog. Ser. 115, 87-92.

Ponis, E., Probert, I., Veron, B., Mathieu, M., Robert, R., 2006. New microalgae for the Pacific oyster Crassostrea gigas larvae. Aquaculture 253, 618-627. 
Rico-Villa, B., Le Coz, J.R., Mingant, C., Robert, R., 2006. Influence of phytoplankton diet mixtures on microalgae consumption, larval development and settlement of the Pacific oyster Crassostrea gigas (Thunberg). Aquaculture 256, 377-388.

Rico-Villa, B., Woerther, P., Mingant, C., Hamon, M., Pouvreau, S., Lepiver, D., Robert, R., 2008. A flow-through rearing system for ecophysiological studies of Pacific oyster Crassostrea gigas larvae. Aquaculture 282, 54-60.

Sicard, M.T., Maeda-Martínez, A.N., Lluch-Cota, S.E., Lodeiros-Seijo, C., Roldán-Carrillo, L.M., Mendoza-Alfaro, R., 2006. Frequent monitoring of temperature: an essential requirement for site selection in bivalve aquaculture in tropical-temperate transition zones. Aquacult. Res. 37, 1040-1049.

Sprung, M., 1984. Physiological energetic of mussel larvae (Mytilus edulis). II. Food uptake. Mar. Ecol. Prog. Ser. 17, 295-305.

Strathmann, R.R., 1978. The evolution and loss of feeding larval stages of marine invertebrates. Evolution 32, 894-906. 